\title{
IMPLEMENTASI METODE FUZZY MAMDANI DAN LINEAR CONGRUENTIAL GENERATOR (LCG) PADA GAME HIDDEN OBJECT
}

\author{
Roki Syah Al Zarkasi ${ }^{1}$, Dhebys Suryani Hormansyah ${ }^{2}$, Dimas Wahyu Wibowo ${ }^{3}$ \\ 1,2,3 Teknik Informatika, Teknologi Informasi, Politeknik Negeri Malang \\ ${ }^{1}$ Rokisyah11@gmail.com, ${ }^{2}$ dhebys.suryani@gmail.com, ${ }^{3}$ dimas.w@polinema.ac.id
}

\begin{abstract}
Abstrak
Game dewasa ini telah menjadi populer di kalangan masyarakat, sebagai suatu bentuk hiburan, mendukung interaksi sosial antara mereka. Game atau permainan sejatinya dibuat untuk digunakan sebagai sarana menghibur. Game hidden object merupakan salah satu konsep game yang ada pada genre game puzzle. Game puzzle merupakan salah satu permainan yang dapat mengasah otak dan sangat menantang. Metode Linear Congruential Genetator (LCG) digunakan untuk membangkitkan bilangan acak dengan distribusi uniform. Random number atau bilangan acak adalah sebuah bilangan yang dihasilkan dari sebuah proses, yang keluarannya tidak dapat diprediksi. Logika Fuzzy adalah peningkatan dari logika Boolean yang mengenalkan konsep kebenaran sebagian. Fuzzy Mamdani merupakan salah satu model dalam metode fuzzy yang sudah umum digunakan. Fuzzy mamdani sering juga dikenal dengan nama Metode Max-Min. Selain itu metode fuzzy mamdani terkenal sederhana dan tidak banyak proses komputasi yang dilakukan dimana proses komputasi dapat membuat sistem akan berjalan lebih lama. Penelitian ini berfokus pada implementasi metode LCG untuk mengacak list object yang ada pada game secara random, dan metode Fuzzy mamdani untuk menghitung skor dan sebagai penentuan level. Fokus Dari penelitian adalah untuk mencai tahu apakah metode LCG dan juga metode fuzzy mamdani dapat diimplemntasikan dengan baik pada game dengan konsep hidden object. Dari hasil implementasi fuzzy mamdani dan LCG didapati bahwa fuzzy mamdani memiliki tingkat keakuratan perhitungan sebesar 98,5\% sedangkan LCG memiliki keakuratan pengacakan list objek sebesar 100\%. Sehingga dapat ditarik kesimpulan bahwa metode fuzzy mamdani dan LCG dapat di implementasikan dengan baik pada game dengan konsep hidden object.
\end{abstract}

Kata kunci: Game, Hidden object, LCG, Fuzzy Mamdani

\section{Pendahuluan}

Game merupakan suatu industri yang sedang marak perkembanganannya di pasar global. Industri game yang semakin maju menyuguhkan sebuah dunia maya yang baru yang terus menerus berkembang untuk mencoba mendekati kehidupan nyata. Game online di masa sekarang begitu populer di berbagai kalangan, salah satunya populer di antara anak sekolah. Anak sekolah merupakan kelompok yang mudah terpengaruh oleh game online terutama anak sekolah dasar, karena sekolah dasar terutama diusia 10-12 tahun seperti itu anak-anak lebih memahami dan masih suka bermain. Game atau permainan dibuat untuk digunakan sebagai sarana menghibur diri maupun untuk menghilangkan rasa penat. Game memiliki dua pengertian, pertama sebuah aktifitas bermain yang murni mencari kesenangan tanpa mencari hasil menang atau kalah dan yang kedua dapat diartikan sebagai aktifitas bermain yang dilakukan dalam rangka mencari kesenangan dan kepuasan.

Game sebagai suatu bentuk hiburan, mendukung interaksi sosial antara mereka, dengan perkembangan ilmu komputer dan platform hardware yang kuat, komputer telah memberikan potensi penuh untuk melakukannya, Pemain game secara rutin menghabiskan ratusan bahkan ribuan jam untuk menguasai keterampilan kompleks dunia digital yang memakan banyak waktu. Jenis animasi pada permainan yang ada juga bervariasi dan memiliki 4 standar, seperti Animasi 2D maupun 3D, Stop Motion, Tradisional dan Kombinasi. Variasi genre pada game telah banyak berkembang seperti strategy (RTS) game, role-player game (RPG), firstperson shooter (FPS) game, business game, racing game dan game puzzle.

Game hidden object merupakan salah satu konsep yang ada pada genre game puzzle. Game puzzle merupakan salah satu permainan yang dapat mengasah otak dan sangat menantang. Meski game puzzle ini identik untuk anak-anak akan tetapi orang dewasapun belum tentu dapat dengan mudah menyelesaikan game tersebut. Pemain ditantang untuk berpikir kreatif bagaimana cara untuk menyelesaikan teka-teki sesuai dengan objektif pada game. Game puzzle sendiri sudah cukup lama hadir pada industry game. Meski begitu rupanya game 
dengan genre ini masih cukup banyak peminatnya, oleh karena itu penulis ingin merancang suatu game bergenre game puzzle dengan konsep game hidden object berbasis 2D dengan cerita dan gameplay yang menarik. Untuk membuat sebuah game yang menarik tentunya dibutuhkan beberapa metode, pada penelitian ini menggunakan Metode Linear Congruential Generators (LCG) dan Fuzzy Mamdani. Metode LCG adalah salah satu pembangkit bilangan acak tertua dan sangat terkenal.

Dari uraian diatas maka peneliti tertarik untuk melakukan penelitian berupa membangun sebuah game puzzle hidden object dengan mengimplementasikan metode LCG dan Fuzzy mamdani, dimana metode LCG berfungsi untuk mengacak list object yang ada pada game secara random, sedangkan metode Fuzzy mamdani berfungsi untuk perhitungan skor dan penentuan level.

\section{Tinjauan Pustaka}

Metode algoritma yang digunakan dalam penelitian ini adalah Metode LCG dan juga metode Fuzzy Mandani.

\section{A. Metode Fuzzy Mamdani}

Metode mamdani sering juga dikenal dengan nama Metode Max-Min. Metode ini diperkenalkan oleh Ebrahim Mamdani pada tahun 1975. Untuk mendapatkan output, diperlukan empat tahapan yaitu:

1) Pembentukan himpunan fuzzy. Pada metode mamdani, baik variable input maupun variable output dibagi menjadi satu atau lebihb himpunan fuzzy.

2) Aplikasi fungsi implikasi (aturan). Pada metode mamdani, fungsi implikasi yang digunakan adalah min.

3) Komposisi aturan. Pada mamdani ada tiga metode yang digunakan dalam melakukan inferensi system fuzzy, yaitu max, additive dan probabilistic OD (probor).

4) Penegasan (defuzzy). Input dari proses defuzzy adalah suatu himpunan fuzzy yang diperoleh dari komposisi aturan-aturan fuzzy,sedangkan output yang dihasilkan merupakan suatu bilangan pada domain himpunan fuzzy tersebut. Sehingga jika diberikan suatu himpunan fuzzy dengan range tertentu, maka harus dapat diambil suatu nilai crisp tertentu7 sebagai output. Ada beberapa metode defuzzy yang bias digunakan pada komposisi aturan mamadani, yaitu centroid, bosektor, mean of maximum, largest of maximum dan smallest of maximum.

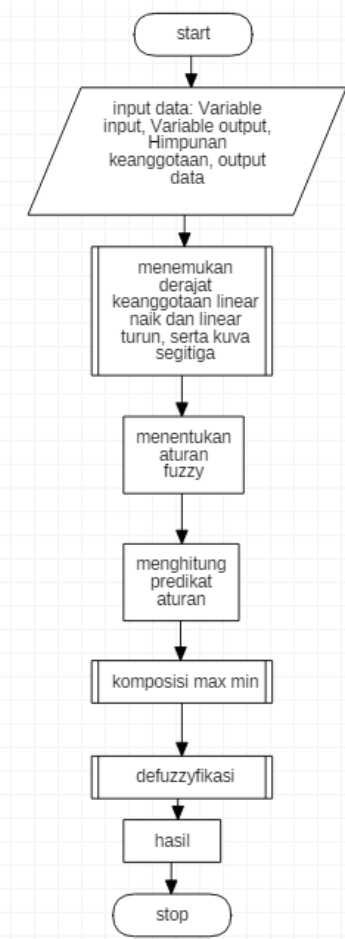

Gambar 1. Flowchart Fuzzy Mamdani

Dalam beberapa penelitan ternyata di dapati hasil bahwa logika fuzzy dengan menggunakan metode mamdani memiliki tingkat error yang relatif lebih kecil ketimbang logika fuzzy metode sugeno[4. Selain itu, pada metode fuzzy mamdani sendiri terkenal lebih sederhana dan tidak banyak proses komputasi yang dilakukan dimana proses komputasi dapat membuat sistem akan berjalan lebih lama.

\section{B. Metode LCG}

Linear congruential generators (LCG) adalah salah satu pembangkit bilangan acak tertua dan sangat terkenal. LCG adalah algoritma yang sering diimplementasikan pada beberapa bahasa pemrograman untuk membangkitkan bilangan acak. LCG didefenisikan dalam relasi rekurens:

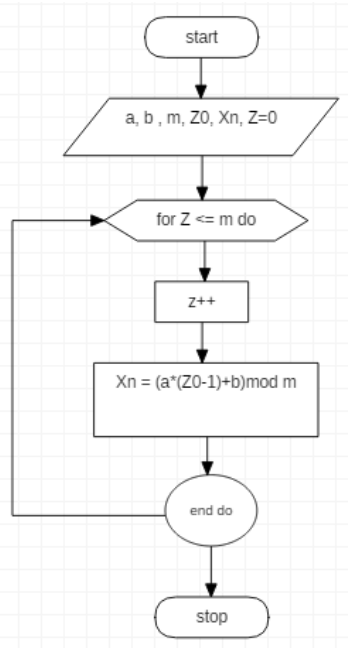

Gambar 2. Flowchart LCG 
Kunci pembangkit adalah X0 yang disebut seed (secret seed). LCG mempunyai periode tidak lebih besar dari m, dan pada kasus periodenya kurang dari itu. LCG mempunyai periode penuh $(m-l)$ jika memenuhi syarat berikut:

1. $b$ relative prima terhadap $m$

2. a-1 dapat dibagi dengan semua faktor prima dari $m$

3. $\mathrm{m}>$ maks $(\mathrm{a}, \mathrm{b}, \mathrm{x} 0)$

4. $a>0, b>0$

Meskipun LCG secara teoritis mampu menghasilkan bilangan acak yang lumayan, namun sangat sensitive terhadap pemilihan nilai-nilai yang tidak sesuai dapat mempengaruhi implementasi pada LCG. LCG tidak dapat digunakan untuk kriptografi karena bilangan acaknya dapat diprediksi urutan kemunculannya. Oleh karena itu LCG tidak aman digunakan untuk kriptografi. Namun demikian, LCG tetap berguna untuk aplikasi non-kriptografi seperti simulasi, sebab LCG memperlihatkan sifat statistik yang bagus dan sangat tepat (Putranto, 2010).

\section{Metodologi}

\subsection{Metode Pengambilan Data}

Metode pengambilan data yang digunakan dalam penelitian ini adalah pengumpulan data penunjang yang dilakukan dengan pengambilan data - data dari buku dan internet tentang game hidden object dengan menggunakan metode Fuzzy Mamdani dan LCG yang digunakan sebagai landasan teori dalam penulisan laporan ini. Data yang digunakan dalam pembuatan game ini adalah aset karakter dan objek yang akan dimainkan dalam setiap level.

\subsection{Metode Pengembangan}

Untuk metode pengembangan perangkat lunak, penulis menggunakan metode waterfall. "Waterfall" adalah metode yang menggambarkan pendekatan yang sistematis dan juga berurutan pada pengembangan perangkat lunak, dimulai dengan spesifikasi kebutuhan pengguna lalu berlanjut melalui tahapan-tahapan perencanaan (planning), permodelan (modeling), konstruksi (construction), serta penyerahan sistem ke para pelanggan/pengguna (deployment), yang diakhiri dengan dukungan pada perangkat lunak lengkap yang dihasilkan.

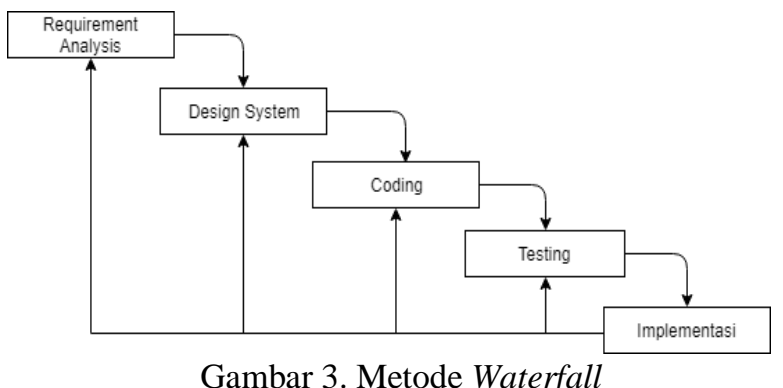

Tahapan - tahapan yang dilakukan sebagai berikut: a. Requirement Analysis

Pada tahap ini penulis melakukan Analisa kebutuhan yaitu mendefinisikan semua kebutuhan dan garis sistem yang akan dibuat. Kebutuhan yang diperlukan dalam pembuatan game "Hidden Object" ini yaitu antara lain asset objek, asset karakter dan audio.

\section{b. Design System}

Desain sistem dalam membuat rancangan implementasi sistem ini adalah dengan mulai merancang flowchart sistem, flowchart LCG dan flowchart fuzzy Mamdani yang akan diimplementasikan pada game "Hidden Object".

\section{c. $\quad$ Coding}

Setelah merancang gambaran sistem penulis mulai memasuki tahapan coding dengan membuat aplikasi game "Hidden Object" dengan menggunakan metode LCG untuk pengacakan dan metode Fuzzy Mamdani untuk pengecekan skor. Pada tahap ini penulis melakukan coding dengan menggunakan unity sebagai platformnya.

\section{d. $\quad$ Testing}

Setelah proses coding pembuatan game "Hidden Object" sudah menjadi suatu perangkat lunak yang siap pakai, dilakukan proses pengecekan terlebih dahulu sebelum digunakan. Pengujian ini dilakukan dengan melakukan pengujian Black Box yang digunakan untuk mengecek apakah fitur yang terdapat pada game "Hidden Object" sudah sesuai dengan perancangan yang telah dibuat.

\section{e. Implementasi}

Pada tahap implementasi ini memiliki arti game yang dibuat telah selesai dan dapat dilakukan implementasi untuk anak SD.

\subsection{Perancangan}

Perancangan sistem ini dibangun dengan tujuan untuk membantu implementasi game hidden object "Rumah Agnes" dengan menggunakan metode Fuzzy Mamdani dan LCG. Game ini dijalankan dengan mencari objek yang tersembunyi dan memiliki 3 level untuk menyelesaikan game ini. 


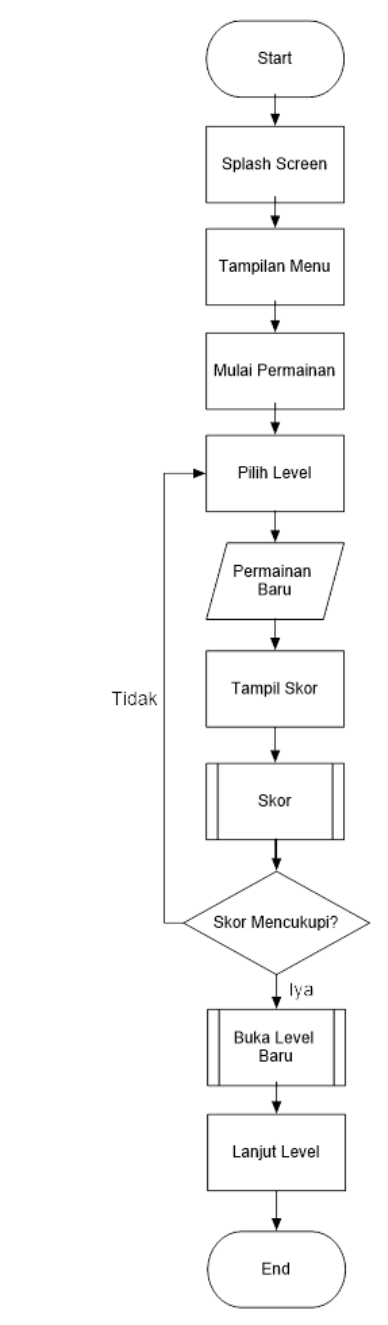

Gambar 4.Flowchart Sistem

Alur sistem sistem game dengan metode Linear congruential generator dan Fuzzy mamdani dalam bentuk flowchart adalah sebagai berikut :

a. Metode LCG akan di terapkan pada proses permainan baru. Yaitu sebagai media pengacakan daftar objek yang di minta pada permainan.

b. Metode Fuzzy Mamdani akan di terapkan pada proses perhitungan skor pada setiap ahir permainan dan sebagai penentu apakah skor yang telah di raih oleh player cukup untuk membuka level berikutnya.

\section{Hasil dan Pembahasan}

Pada bab ini akan dijelaskan hal-hal yang berkaitan dengan perancangan aplikasi, dimulai dengan deskripsi umum mengenai aplikasi yang dibuat, perancangan proses-proses yang ada, dan alur proses.

\section{a. Deskripsi Program}

Game rumah agnes adalah permainan dengan mengusung konsep hidden object game. Tujuan dari di buatnya game ini adalah untuk melihat kecocokan metode Fuzzy Mamdani dan juga LCG ketika di gunakan untuk membangun game hidden object.

\section{b. Tampilan Game}

Tampilan Game dari penelitian game hidden object Rumah Agnes yang mengimplementasikan metode LCG dan metode fuzzy mamdani.

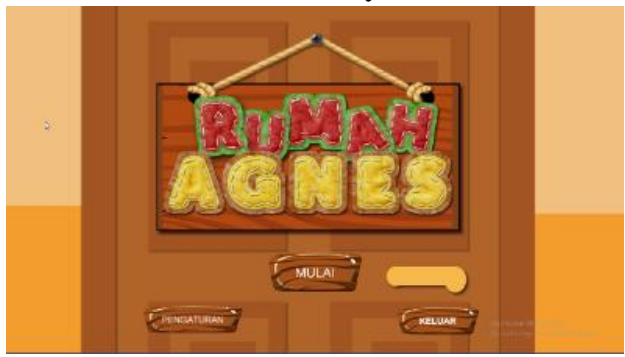

Gambar 5.Tampilan Halaman Utama

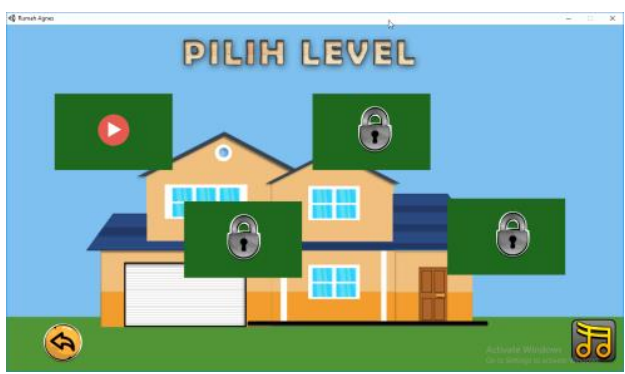

Gambar 6. Tampilan Pilih Level

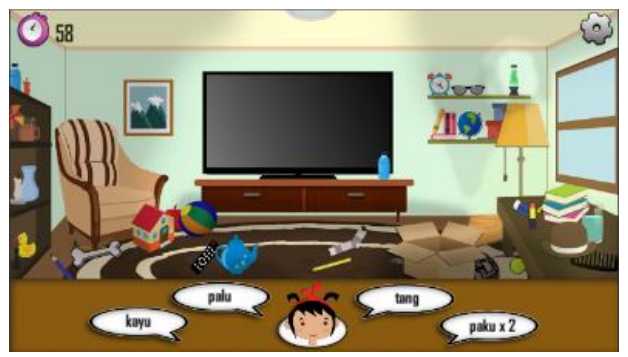

Gambar 6. Tampilan Permainan

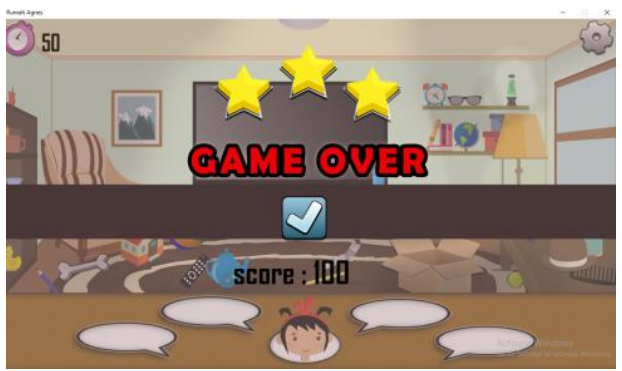

Gambar 6. Tampilan Skor

\section{Pengujian dan Pembahasan}

Pengujian sistem yang dilakukan pada game ini menggunakan pengujian Black box. Pengujian tersebut dilakukan untuk mengevaluasi hasil sistem yang dibuat.

\section{a. Pengujian Fungsional}

Pengujian fungsional digunakan untuk menguji sistem yang telah dibuat dengan metode pengujian BlackBox. 
Tabel 1. Daftar pengujian fungsional Game Rumah Agnes.

\begin{tabular}{|c|c|c|c|c|}
\hline No. & $\begin{array}{c}\text { Aktifitas } \\
\text { yang di } \\
\text { Uji }\end{array}$ & $\begin{array}{c}\text { Skenario } \\
\text { Uji }\end{array}$ & $\begin{array}{c}\text { Hasil yang } \\
\text { Diharapkan }\end{array}$ & $\begin{array}{r}\text { Hasil } \\
\text { Uji }\end{array}$ \\
\hline 1. & $\begin{array}{l}\text { Tampilan } \\
\text { awal }\end{array}$ & $\begin{array}{l}\text { Terdapat } \\
\text { tampilan } \\
\text { menu utama }\end{array}$ & $\begin{array}{l}\text { Halaman utama } \\
\text { terdiri dari } \\
\text { mulai, } \\
\text { informasi, } \\
\text { keluar dan } \\
\text { tombol musik }\end{array}$ & $\begin{array}{l}\text { Berha } \\
\text { sil }\end{array}$ \\
\hline 2. & Informasi & $\begin{array}{l}\text { Memilih } \\
\text { tombol } \\
\text { informasi } \\
\text { untuk } \\
\text { membaca } \\
\text { informasi } \\
\text { dari game. }\end{array}$ & $\begin{array}{l}\text { Berisi tentang } \\
\text { dari permainan } \\
\text { dan bidoata } \\
\text { pembuat. }\end{array}$ & $\begin{array}{l}\text { Berha } \\
\text { sil }\end{array}$ \\
\hline 3. & $\begin{array}{l}\text { Tombol } \\
\text { mulai }\end{array}$ & $\begin{array}{l}\text { Untuk } \\
\text { masuk } \\
\text { kedalam } \\
\text { halaman } \\
\text { pilih level }\end{array}$ & $\begin{array}{l}\text { Masuk kedalam } \\
\text { halaman pilih } \\
\text { level permainan. }\end{array}$ & $\begin{array}{l}\text { Berha } \\
\text { sil }\end{array}$ \\
\hline 4. & $\begin{array}{l}\text { Tombol } \\
\text { keluar }\end{array}$ & $\begin{array}{l}\text { Memilih } \\
\text { tombol } \\
\text { keluar untuk } \\
\text { keluar dari } \\
\text { permainan }\end{array}$ & $\begin{array}{l}\text { Ketika memilih } \\
\text { tombol keluar } \\
\text { maka akan } \\
\text { keluar dari } \\
\text { aplikasi }\end{array}$ & $\begin{array}{l}\text { Berha } \\
\text { sil }\end{array}$ \\
\hline 5. & $\begin{array}{l}\text { Tombol } \\
\text { musik }\end{array}$ & $\begin{array}{l}\text { Memilih } \\
\text { tombol } \\
\text { musik untuk } \\
\text { mematikan/ } \\
\text { menghidupk } \\
\text { an musik }\end{array}$ & $\begin{array}{l}\text { Ketika memilih } \\
\text { tombol musik } \\
\text { maka semua } \\
\text { musik game } \\
\text { akan on/off }\end{array}$ & $\begin{array}{l}\text { Berha } \\
\text { sil }\end{array}$ \\
\hline 6. & $\begin{array}{l}\text { Tampilan } \\
\text { pilih } \\
\text { level }\end{array}$ & $\begin{array}{l}\text { Tampilan } \\
\text { pilih level } \\
\text { yang berisi } \\
\text { daftar dari } \\
\text { level yang } \\
\text { bisa } \\
\text { dimainkan }\end{array}$ & $\begin{array}{l}\text { Tampilan pilih } \\
\text { level berisi dari } \\
\text { scene level yang } \\
\text { dapat di } \\
\text { mainkan dan } \\
\text { tombol back } \\
\text { untuk kembali } \\
\text { ke halaman } \\
\text { utama. }\end{array}$ & $\begin{array}{l}\text { Berha } \\
\text { sil }\end{array}$ \\
\hline 7. & $\begin{array}{l}\text { Tombol } \\
\text { back }\end{array}$ & $\begin{array}{l}\text { Untuk } \\
\text { kembali ke } \\
\text { halaman } \\
\text { sebelumnya }\end{array}$ & $\begin{array}{l}\text { Tombol untuk } \\
\text { kembali } \\
\text { kehalaman } \\
\text { sebelumnya }\end{array}$ & $\begin{array}{l}\text { Berha } \\
\text { sil }\end{array}$ \\
\hline 8. & $\begin{array}{l}\text { Tombol } \\
\text { Pause }\end{array}$ & $\begin{array}{l}\text { Tombol } \\
\text { untuk } \\
\text { menghentik } \\
\text { an } \\
\text { permainan } \\
\text { sementara }\end{array}$ & $\begin{array}{l}\text { Tombol untuk } \\
\text { menghentikan } \\
\text { permainan } \\
\text { secara } \\
\text { sementara. }\end{array}$ & $\begin{array}{l}\text { Berha } \\
\text { sil }\end{array}$ \\
\hline 9. & $\begin{array}{l}\text { Panel } \\
\text { daftar } \\
\text { objek }\end{array}$ & $\begin{array}{l}\text { Berisi daftar } \\
\text { objek yang } \\
\text { harus dicari. }\end{array}$ & $\begin{array}{l}\text { Berisi daftar } \\
\text { objek yang } \\
\text { harus di } \\
\text { temukan oleh } \\
\text { pemain. }\end{array}$ & $\begin{array}{l}\text { Berha } \\
\text { sil }\end{array}$ \\
\hline
\end{tabular}

\begin{tabular}{|c|c|c|c|c|}
\hline 11. & $\begin{array}{l}\text { Tombol } \\
\text { reset }\end{array}$ & $\begin{array}{l}\text { Untuk } \\
\text { melakukan } \\
\text { reset dari } \\
\text { level yang } \\
\text { sedang } \\
\text { dimainkan }\end{array}$ & $\begin{array}{l}\text { Tombol untuk } \\
\text { melakukan reset } \\
\text { dari level yang } \\
\text { sedang } \\
\text { dimainkan. }\end{array}$ & $\begin{array}{l}\text { Berha } \\
\text { sil }\end{array}$ \\
\hline 12. & $\begin{array}{l}\text { Tombol } \\
\text { home }\end{array}$ & $\begin{array}{l}\text { Untuk } \\
\text { kembali ke } \\
\text { halaman } \\
\text { pilih level }\end{array}$ & $\begin{array}{l}\text { Untuk kembali } \\
\text { ke halaman } \\
\text { pilih level }\end{array}$ & $\begin{array}{l}\text { Berha } \\
\text { sil }\end{array}$ \\
\hline 13. & $\begin{array}{l}\text { Tombol } \\
\text { continue }\end{array}$ & $\begin{array}{l}\text { Untuk } \\
\text { melanjutkan } \\
\text { permainan } \\
\text { pada saat } \\
\text { game } \\
\text { sedang di } \\
\text { pause }\end{array}$ & $\begin{array}{l}\text { Untuk } \\
\text { melanjutkan } \\
\text { permainan yang } \\
\text { sedang di } \\
\text { pause. }\end{array}$ & $\begin{array}{l}\text { Berha } \\
\text { sil }\end{array}$ \\
\hline 14. & $\begin{array}{l}\text { Panel } \\
\text { objek }\end{array}$ & $\begin{array}{l}\text { Berisi objek } \\
\text { objek yang } \\
\text { sedang di } \\
\text { sembunyika } \\
\text { n dan harus } \\
\text { di cari oleh } \\
\text { pemain }\end{array}$ & $\begin{array}{l}\text { Berisi gambar } \\
\text { objek yang } \\
\text { dicari oleh } \\
\text { pemain. }\end{array}$ & $\begin{array}{l}\text { Berha } \\
\text { sil }\end{array}$ \\
\hline 15. & $\begin{array}{l}\text { Tampilan } \\
\text { akhir } \\
\text { permaina } \\
\mathrm{n}\end{array}$ & $\begin{array}{l}\text { Tampilan } \\
\text { yang } \\
\text { muncul di } \\
\text { akhir } \\
\text { permainan }\end{array}$ & $\begin{array}{l}\text { Tampilan akhir } \\
\text { permainan dari } \\
\text { setiap level }\end{array}$ & $\begin{array}{l}\text { Berha } \\
\text { sil }\end{array}$ \\
\hline 16. & Skor & $\begin{array}{l}\text { Skor dari } \\
\text { permainan }\end{array}$ & $\begin{array}{l}\text { Skor akhir dari } \\
\text { setiap } \\
\text { permainan }\end{array}$ & $\begin{array}{l}\text { Berha } \\
\text { sil }\end{array}$ \\
\hline
\end{tabular}

\section{b. Pengujian Fuzzy Mamdani}

Pengujian fuzzy mamdani dilakukan dengan melakukan percobaan permainan 10 kali dengan memasukan beberapa variabel input berbeda yang kemudia dicocokan dengan hasil dari perhitungan excel dan didapati bahwa dari 10 kali percobaan program dapat menjalankan metode fuzzy dengan cukup baik dengan total tingkat keakuratan $98.5 \%$

Tabel 2. Hasil Pengujian Fuzzy Mamdani

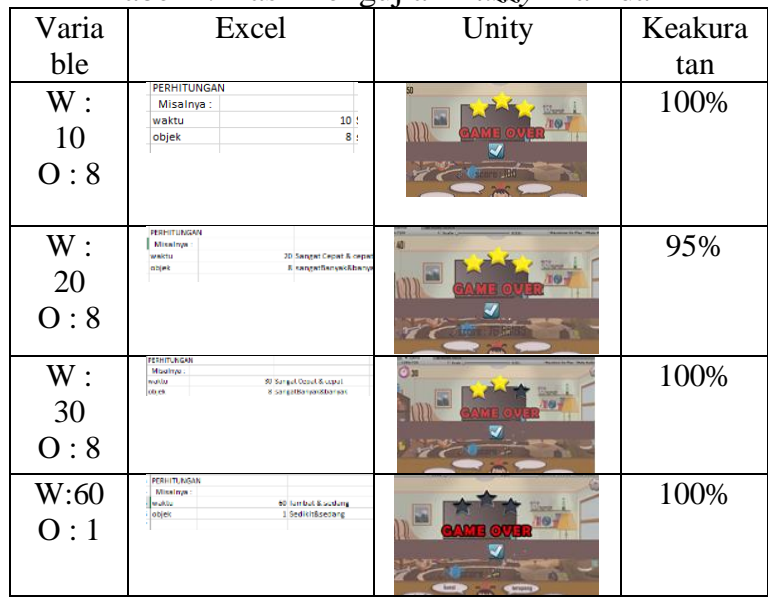




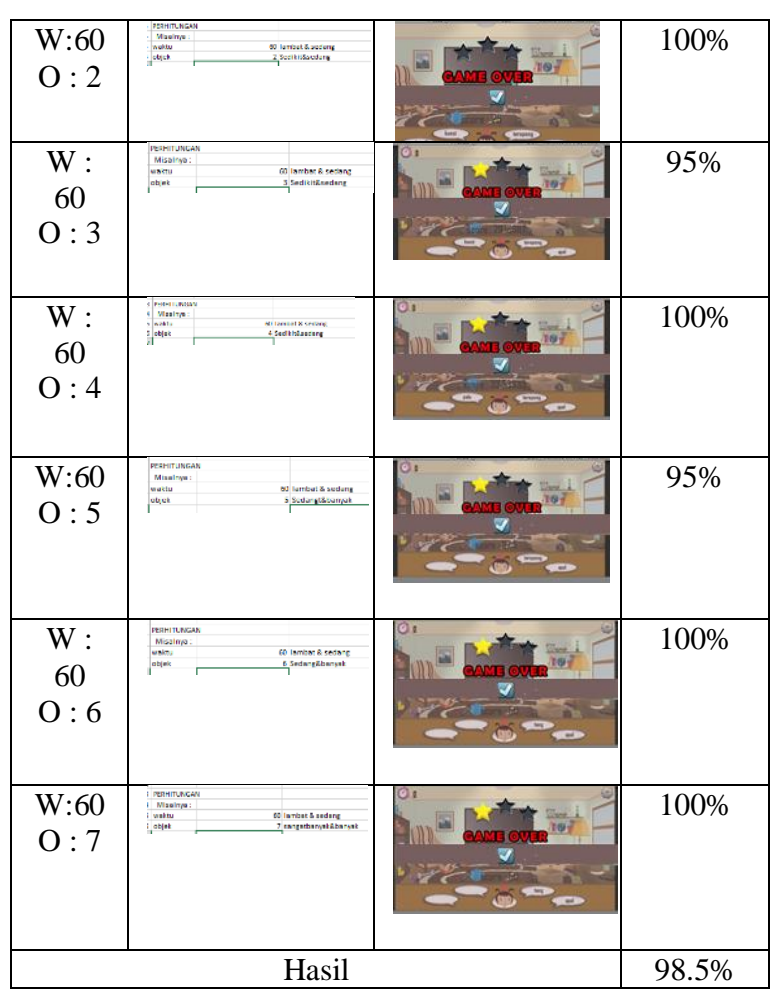

c. Pengujian LCG

Tabel 3. Hasil Pengujian $L C G$

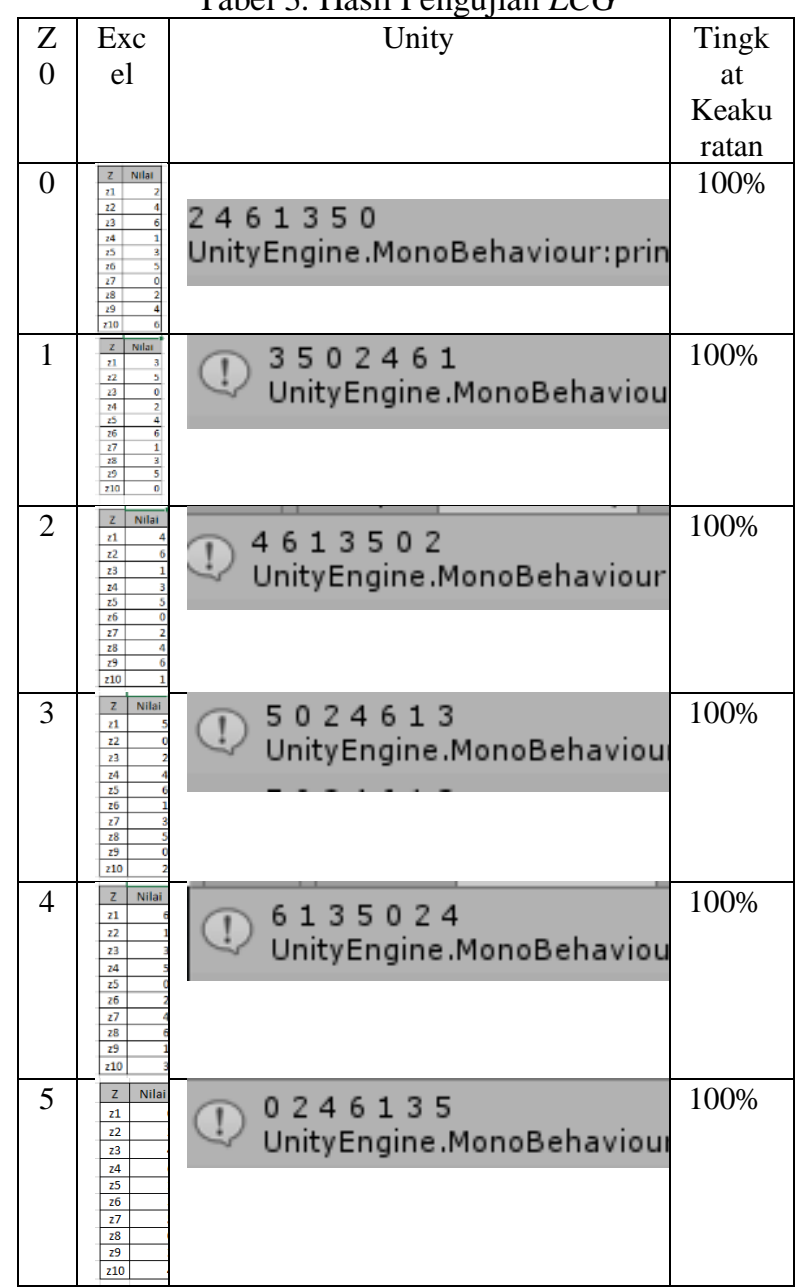

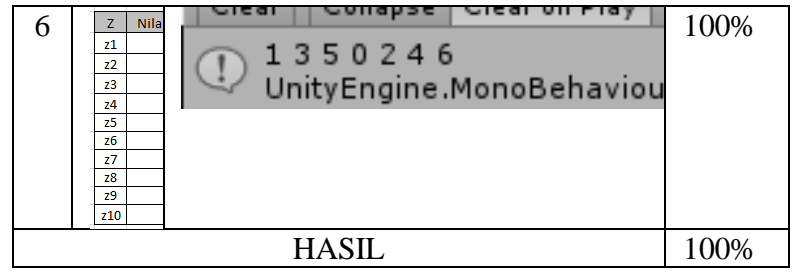

Dari 6 kali pengujian dengan menggunakan 6 kali faktor pengali yang berbeda di dapati hasil dari unity sesuai persis dengan perhitungan yang ada pada excel, sehingga dapat ditarik kesimpulan bahwa metode LCG dapat berjalan dengan baik pada game.

\section{Kesimpunal dan saran}

\subsection{Kesimpulan}

Berdasarkan hasil analisis, perancangan, implementasi yang telah dilakukan terdapat beberapa kesimpulan yaitu:

1. Dalam pembuatan game 2D dengan tema hidden object lebih berfokus pada pembuatan asset pada game nya, dikarenakan game dengan bertema puzzle seperti hidden object ini diperlukan banyak sekali asset agar dapat memberikan gameplay permainan yang lebih menarik dan tidak membosankan bagi pemain.

2. Dari penelitian yang dilakukan didapati bahwa metode fuzzy mamdani dapat berjalan dengan baik dalam perhitungan skor dan cocok untuk diimplementasikan pada game dengan genre hidden object, hal itu dapati dilihat dari nilai pengujian yang cukup tinggi dengan nilai ke akuratan mencapai $98,5 \%$.

3. Dari penelitian ini juga didapati bahwa metode pengacakan LCG dapat berjalan dengan baik ketika diimplementasikan kedalam game dengan genre hidden object, itu dapat dilihat dari hasil penelitian yang mampu menunjukan nilai yang sangat memuaskan yaitu dengan nilai keakuratan $100 \%$ pada pengacakan nya.

\subsection{Saran}

Berdasarkan penelitian yang dilakukan, dapat diajukan beberapa saran sebagai berikut:

4. Game "Rumah Agnes" dapat di mainkan juga di platform mobile.

5. Game "Rumah Agnes" di tambah fitur untuk melakukan share skor tertinggi yang dapat di raih oleh player.

Daftar Pustaka:

Marlianti Dewi. 2015."Hubungan Kecanduan Bermain Game Online dengan Pola Tidur dan Motivasi Belajar Anak Usia 10-12 Tahun di SD Mattoangin 2 Kecamatan Mariso Kota Makassar".

Latius Hermawan \& Astrid Novita Putri November. 2014."Penerapan Algoritma Fuzzy mamdani untuk Mengatur Game Scoring pada Game Helitap". 
Bobby Prasetyo, Ina Agustina \& M Gufroni. 2017."Perancangan Game Puzzle Pemadam Kebakaran Menggunakan Metode Linear congruential generator (LCG)".

Aan Ageng Wibowo. 2015. "Perbandingan Logika Fuzzy Metode Mamdani dan Fuzzy Metode Sugeno dalam Penentuan Jumlah Produksi”.

Martinus Maslim. 2013. "Aplikasi Logika Fuzzy Pada Sistem Pakar Pariwisata".

M. Surya Ikhsan, Tjipto Suryadi, Yoannita \& Renni Angreni.2014."Rancang bangun hidden object edugame sebagai alternatif pembelajaran vocabulary bahasa inggris berbasis android".

Ade Leonardo, Bambang Satriawan \& Fithri Selva Jumeilah. 2015. "Penerapan logika fuzzy mamdani pada permainan battle tank"

Riki Wahyudi \& Hendra Handoko Syahputra Pasaribu. 2015. "Perancangan Aplikasi Quiz Menggunakan Metode Pengacakan Linear congruential generator (LCG) Berbasis Android".

Dora Irsa, Rita Wiryasaputra \& Sri Primaini. 2014. "Perancangan aplikasi game edukasi pembelajaran anak usia dini menggunakan linear congruent method (LCM) berbasis android".

Reo Angga Ardenia Alexius Endy Budianto. 2013. "penerapan metode fuzzy untuk game keselamatan pengendara sepeda motor berbasis android".

Anik Vega Vitianingsih. 2006. "Game Edukasi Sebagai Media Pembelajaran Pendidikan Anak Usia Dini”. 
Volume 6, Edisi 4, Agustus 2020

30| H a 1 a $m$ a n 